\title{
IZRADA PRAVNIH PROPISA U SUSTAVU VISOKOG OBRAZOVANJA U VRIJEME PANDEMIJE COVID-A 19
}

\author{
$U D K: 34: 378$ \\ $378: 616.2-036.21$ \\ DOI: $10.31141 /$ zrpfs.2021.58.140.501 \\ Stručni rad \\ Primljeno: 6. 2. 2021.
}

\begin{abstract}
Autor analizira izradu i donošenje pravnih propisa u području visokog obrazovanja kao javne službe u Republici Hrvatskoj u doba pandemije bolesti COVID-19. Ističe kako javne službe, napose visoko obrazovanje, nisu bile pripremljene za rad i djelatnost u izvanrednim prilikama zbog ugroze zdravlja i života ljudi u vrijeme pandemije. Na primjerima Sveučilišta u Zagrebu, Hrvatskog zavoda za javno zdravstvo, Stožera civilne zaštite RH i Vlade RH, analizirao je akte koji su doneseni u svrhu provedbe zabrana, naloga, uputa, mjera i preporuka za nesmetano odvijanje djelatnosti visokog obrazovanja. Posebna pozornost posvećena je pravnom mišljenju u pogledu postupka izbora čelnika sastavnica Sveučilišta u Zagrebu te načina odlučivanja kolektivnih tijela Sveučilišta u Zagrebu u doba pandemije. Prijeko je potrebno da sva tijela hrvatske akademske zajednice, sveučilišta i drugih visokih učilišta donesu potrebne akte kojima bi dali legitimitet i legalitet obliku i načinu izvođenja nastave u izvanrednim, pandemijskim okolnostima.
\end{abstract}

Ključne riječi: pravni propisi, visoko obrazovanje, pandemija COVID-a 19, kvaliteta, preporuke

\section{UVOD}

Visoko obrazovanje u Republici Hrvatskoj djelatnost je od posebnog interesa za Republiku Hrvatsku i kao takvo uživa i posebnu zaštitu kroz institut akademske samouprave i autonomije sveučilišta. Autonomija sveučilišta propisana je Ustavom Republike Hrvatske tako da se jamči autonomija sveučilišta te da sveučilište samo odlučuje o svom ustroju i djelovanju, u skladu sa zakonom. Visoko obrazovanje u Republici Hrvatskoj prije svega je organizirano i ustrojeno kao javna služba što ga karakterizira kao djelatnost, službu, od važnosti za društvenu zajednicu odnosno za Republiku Hrvatsku, za njezin znanstveni, kulturni, ekonomski i svekoliki razvitak. Visoko obrazovanje ima obilježje djelatnosti od javnog interesa i u skladu s tim načelima obavlja se kao javna služba, čime je visoko obrazovanje

1 Ivica Šušak, e-mail: ivica.susak@mzo.hr 
podvrgnuto posebnim propisima javnog prava, te je kao takvo podvrgnuto zakonodavnom okviru kojim se uređuje pojam ustanove. Javne službe u Republici Hrvatskoj, napose ustanove u sustavu visokog obrazovanja, visoka učilišta, nisu bile pripremljene za djelovanje u izvanrednim uvjetima. U stanju ugroze zdravlja ljudi, a na području Zagreba i elementarne nepogode u vidu oštećenja imovine i dodatne ugroze života i zdravlja ljudi kao posljedice razornog potresa, normativni okvir koji uređuje sustav visokog obrazovanja u Republici Hrvatskoj nema predviđena pravna pravila odnosno postupke, mjere i uvjete za djelovanje i postupanje u izvanrednim kriznim stanjima. U početnoj fazi primjene drastičnih mjera za zaustavljanje pandemije COVID-a 19 na teritoriju Republike Hrvatske, Grad Zagreb i njegovu okolicu zadesio je razorni potres koji je nanio znatna oštećenja na javnim zgradama i nekretninama u privatnom vlasništvu. Riječ je o dvostrukoj krizi odnosno izvanrednim okolnostima prouzročenima dvojakim razlozima pojavom ugroze zdravlja čovjeka i elementarnom nepogodom koja u konačnici također ima i utjecaj na život i na zdravlje čovjeka i građanina.

Sustav visokog obrazovanja u Republici Hrvatskoj temelji se na sveučilištima kao stožernim ustanovama znanstvene, intelektualne i duhovne snage hrvatskog društva te na veleučilištima i visokim školama kao ustanovama za izvedbu stručnog studija. Danas Republika Hrvatska ima devet javnih sveučilišta na kojima studira najveći broj studenata u Republici Hrvatskoj.

Pitanje pripravnosti i osposobljenosti javnih službi u Republici Hrvatskoj, dakako i javnih sveučilišta, za djelovanje i postupanje u izvanrednim okolnostima nije uređeno potrebama i zahtjevima modernog života. Tranzicija iz tzv. „,socijalističkog društvenog uređenja“"u demokratsko društveno uređenje na osnovama parlamentarne demokracije u svakom je slučaju utjecala na slabu pripremljenost javnih ustanova za izvanredne prilike, ali i na nedostatak normativnog okvira kojim se propisalo postupanje tijela u izvanrednim okolnostima. Sustav javnih sveučilišta nema pravna 
pravila za postupanje u izvanrednim prilikama (Polić Bobić, 2019), ${ }^{2}$ iako je u pitanju javna služba koja obuhvaća iznimno veliki broj korisnika odnosno građana koji koriste službu visokog obrazovanja kroz studiranje na prijediplomskoj, diplomskoj i/ili poslijediplomskoj razini. Kao jedan od uzroka nepostojanja normativnog okvira za postupanje u izvanrednim okolnostima u svakom slučaju je tranzicijsko napuštanje ideološki obojenih i indoktriniranih pravnih pravila u tzv. „sustavu društvene samozaštite" koji je bio u primjeni za vrijeme bivše državne tvorevine Jugoslavije. Usprkos i unatoč svim negativnim elementima takvog normativnog uređenja uz elemente vojne diktature, koja je bila prisutna u svim segmentima društvenog i državnog uređenja bivše državne tvorevine, pravne osobe s javnim ovlastima imale su detaljno propisana pravila postupanja i djelovanja u izvanrednim okolnostima koje su obuhvaćale i elementarne nepogode te ugrozu života i zdravlja čovjeka i građanina. Navedeni sustav postupanja, mjera i uvjeta u izvanrednim okolnostima bio je izrazito ideološki, doktrinarno i vojnodiktatorski obilježen i podvrgnut prije svega psihološkom utjecaju i svojevrsnom pritisku na građane i zaposlenike javnih ustanova. Između ostalog može se zaključiti kako su ideološka indoktrinacija te nedostatak demokratskih uvjeta i demokratskih pravnih pravila utjecali na stanoviti „,bijeg“ od donošenja pravnih pravila koja propisuju i uređuju ovlasti i postupanje javnih ustanova u izvanrednim prilikama.

Bogato hrvatsko iskustvo iz nedavnog Domovinskog rata svakako je trebalo poslužiti pri izradi pravnih pravila za postupanje hrvatskih visokih učilišta $u$ izvanrednim okolnostima ugroze zdravlja i života ljudi.

2 https://www.matica.hr/hr/605/sveuciliste-u-zagrebu-u-republici-hrvatskoj-30252/, pristupljeno 1. rujna 2020., Hrvatska revija 4, 2019., Sveučilište u Zagrebu u Republici Hrvatskoj, Mirjana Polić Bobić: „Skupština Sveučilišta u Zagrebu, uz rektora tada najviše tijelo uprave, 3. rujna 1991. godine donijela je odluku o organizaciji i radu Sveučilišta u Zagrebu u izvanrednim prilikama i ratu. Njome je ono zadržalo svoju mirnodopsku organizaciju i funkciju, ali ih je prilagođavalo ratnim uvjetima. Njome su određene dužnosti i ovlasti uprave i tijela uprave, a za obavljanje operativnih poslova u uvjetima izvanrednih prilika i rata te vođenja obrane i zaštite osnovan je stožer, »Operativni štab Sveučilišta u Zagrebu«, s točno određenim dužnostima i načinima koordiniranja stožera koje su tada osnivale njegove sastavnice te s popisom mjera koje treba inicirati i provesti. U tom su okviru postojale i studentske straže, koje su čuvale studente i imovinu najprije samo u studentskim domovima, a od listopada 1991. i sve sastavnice Sveučilišta. Štab je djelovao do ožujka 1992., a nakon toga ostalo je djelatno njegovo Odjeljenje za poslove obrane i zaštite radi vrlo složenog posla razvijanja sustava sigurnosti u području akata koji ga reguliraju i praktičnih zadataka koji su uključivali ljudske i materijalne potencijale Sveučilišta: organiziran je prihvat i pomoć profesorima i studentima nakon povratka iz vojske, održavanje reda u studentskim domovima, sigurnost svih zgrada sveučilišta radi normalnog odvijanja svakodnevnog rada itd. U tom je najtežem razdoblju Sveučilište u Zagrebu kao cjelina dalo doista golem doprinos obrani Hrvatske. Izradilo je katalog projekata/usluga (službi) koje mogu povećati obrambenu sposobnost zemlje i ponudilo ga Uredu Predsjednika Republike i Vladi Republike Hrvatske. Neizmjerna je pomoć znanstvenika pružena u ekspertizama zločina nad civilnim stanovništvom, medicinskim osobljem, u otkrivanju ubacivanih izvora bolesti i sl., u dragovoljnom pristupanju sanitetskim jedinicama, u svakovrsnoj tehničkoj pomoći u okolnostima totalnoga fizičkog razaranja - od jednostavne do najrazrađenije, u kontroli vode, u zaštiti spomeničke baštine, u prevođenju dokumentacije o razaranju na strane jezike i njezinu slanju na mnoge adrese u inozemstvu, u organiziranju i provedbi brige za psihičko i fizičko zdravlje te za smještaj izbjeglica i u mnoštvu drugih aktivnosti na najrazličitijim područjima. Pokrenut je i četverosemestralni interdisciplinarni studij poslovne informatike, osmišljen u prvom redu za invalide Domovinskog rata: on je tim mladim ljudima, pretežito dragovoljcima, omogućavao razmjerno brzo stjecanje zvanja kojim su se mogli uspješno integrirati u poslovni svijet, i u idućih nekoliko godina njih je 250 steklo to zvanje." 


\section{PRVI PROPISI U SUSTAVU VISOKOG OBRAZOVANJA U DOBA PANDEMIJE}

Uvod u postupanje javnih službi, pa tako i područja visokog obrazovanja, označen je dana 28. veljače 2020. Hrvatski zavod za javno zdravstvo (HZJZ) izdao je dodatne upute za kolektive i poslodavce za prilagodbu svakodnevnog života u Republici Hrvatskoj. Za visoka učilišta znakovite su sljedeće upute:

- Koristite telefone, videokonferencije i internet za poslovanje što je više moguće kao zamjenu za sastanke!

- Kada su sastanci neophodni i neodgodivi, organizirajte ih u što većim prostorijama te ostavite dovoljan razmak (najmanje jedan do dva metra) između pojedinih osoba!

- Izbjegavajte rukovanja te potaknite održavanje razmaka od barem jedan metar kod razgovora. Redovito, a najmanje dva puta dnevno, provjetravajte sve prostorije!

- Prostorije za sastanke, edukacije i druge prostore gdje se okuplja veći broj osoba provjetravajte nakon i prije svakog sastanka, tijekom stanke i sl.!

- Izbjegavajte putovanja koja nisu nužna, posebno u zahvaćena područja.

- Svim osobama koje imaju simptome respiratorne bolesti (kašalj, kihanje, povišena tjelesna temperatura, kratak dah) omogućite ostanak kod kuće! ${ }^{3}$

U skladu s uputama Hrvatskog zavoda za javno zdravstvo od 28. veljače 2020., sustav visokog obrazovanja postupno i polagano počeo se prilagođavati pri kraju prve polovice ožujka 2020. Za potrebe ovog rada prikazat ću primjere djelovanja i izrade propisa (općih akata) Sveučilišta u Zagrebu, u vrijeme proglašene pandemije, kao najveće i najstarije hrvatske visokoškolske, znanstvene i umjetničke ustanove. Ustrojstvo, djelovanje, postupanje ovlasti i pravni položaj Sveučilišta uređen je ustavnim normama o autonomiji sveučilišta te slobodi znanstvenog djelovanja i umjetničkog stvaralaštva, ali i općim propisom kojim se uređuje osnivanje i ustrojstvo ustanova, Zakonom o ustanovama te posebnim Zakonom o znanstvenoj djelatnosti i visokom obrazovanju. Uslijed pogoršanja epidemiološke situacije u okruženju Republike Hrvatske, ali i zbog ugroze zdravlja ljudi na području RH, na temelju statutarnih ovlasti propisanim odredbama Statuta Sveučilišta u Zagrebu, rektor Sveučilišta u Zagrebu prof. dr. sc. Damir Boras donio je dana 11. ožujka 2020. Odluku o imenovanju Kriznoga stožera Sveučilišta u Zagrebu vezano uz COVID-19. ${ }^{4}$ Zadatak je Kriznoga stožera praćenje razvoja događaja vezanih uz COVID-19 te davanje preporuka upravi Sveučilišta u Zagrebu u skladu s aktualnom epidemiološkom situacijom. U stožer su imenovani: ravnateljica Škole narodnoga

3 Prema Hrvatski zavod za javno zdravstvo - služba za medicinu rada, Upute za poslodavce i radnike vezano uz nCOV bolesti (COVID-19) Klasa: 008-02/20-09/1 Ur.Broj: 381-09-92-20-1 Zagreb, 2. IX. 2020., 13h.

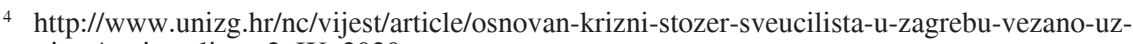
koronavirus/, pristupljeno 2. IX. 2020. 
zdravlja „Andrija Štampar“ Medicinskoga fakulteta Sveučilišta u Zagrebu prof. dr. sc. Mirjana Kujundžić Tiljak, kao predsjednica Kriznoga stožera Sveučilišta u Zagrebu, pročelnica Katedre za infektologiju Medicinskoga fakulteta prof. dr. sc. Adriana Vince, dekan Medicinskoga fakulteta prof. dr. sc. Marijan Klarica, dekanica Stomatološkoga fakulteta prof. dr. sc. Zrinka Tarle, dekan Veterinarskoga fakulteta prof. dr. sc. Nenad Turk i prodekan Veterinarskog fakulteta prof. dr. sc. Ljubo Barbić te prorektorica za studente, studije i upravljanje kvalitetom Sveučilišta u Zagrebu prof. dr. sc. Ivana Čuković-Bagić. Riječ je o prvom općem aktu na Sveučilištu u Zagrebu kojim se stvaraju uvjeti za djelovanje i postupanje Sveučilišta u Zagrebu u uvjetima prijeteće pandemije i ugroze zdravlja čovjeka s ciljem izrade podloge za donošenje drugih pravnih propisa mjera, pravila, uputa i preporuka za djelovanje javne ustanove u sustavu visokog obrazovanja i znanstvene djelatnosti $u$ ipak izvanrednim okolnostima. Analizom općih i pojedinačnih akata drugih javnih sveučilišta dostupnih na njihovim mrežnim stranicama utvrdio sam da je Sveučilište u Zagrebu prvo u Hrvatskoj donijelo pravni propis u svezi s pandemijom.

Već je 12. ožujka 2020. godine rektor Sveučilišta u Zagrebu prof. dr. Damir Boras, na osnovi preporuka osnovanog Kriznog stožera Sveučilišta u Zagrebu vezano uz COVID-19, a temeljem statutarnih ovlasti, donio „Uputu o postupanju“5 kao pravni propis kojim se propisuje postupanje Sveučilišta u Zagrebu, njegovih zaposlenika i svih sastavnica SuZ-a povodom proglašene epidemije. Kroz sedam točaka uputa odgođene su sve aktivnosti koje nisu u izravnoj svezi s nastavom, naložena je mjera samoizolacije uz rad od kuće za sve zaposlenike i studente koji su doputovali ili će doputovati iz inozemstva, propisuje se rad od kuće za kronične bolesnike i nalaže se priprema za eventualnu promjenu oblika izvođenja kontaktne klasične nastave u nastavu na daljinu. Upućuje se na odgađanje svih aktivnosti koje nisu u izravnoj mjeri vezane uz nastavu. Propisuje se da su svi zaposlenici Sveučilišta u Zagrebu koji su u proteklih četrnaest dana boravili izvan Republike Hrvatske dužni javiti se upravi Sveučilišta u Zagrebu i ostati u samoizolaciji za vrijeme koje ce raditi od kuće (ukupno četrnaest dana od dana povratka iz inozemstva). Nadalje, propisana je obveza svim zaposlenicima Sveučilišta da se u slučaju pojave simptoma bolesti moraju javiti nadležnom epidemiologu prema uputama Hrvatskog zavoda za javno zdravstvo. Uputama je naloženo svim sastavnicama Sveučilišta u Zagrebu (fakultetima i umjetničkim akademijama) dužnost svakodnevnog informiranja uprave Sveučilišta u Zagrebu i dostave popisa studenata koji su u samoizolaciji. Svim studentima Sveučilišta u Zagrebu koji su u proteklih četrnaest dana boravili izvan Republike Hrvatske naloženo je da se moraju javiti nadležnom prodekanu za nastavu i za studente na sastavnici na kojoj studiraju, te da moraju ostati u samoizolaciji četrnaest dana od povratka iz inozemstva. Svi studenti u slučaju pojave simptoma bolesti dužni su se javiti nadležnom epidemiologu prema uputama Hrvatskog zavoda za javno zdravstvo. Uputama je propisano da će se svi izostanci studenata s predavanja, seminara vježbi i drugih oblika sveučilišne nastave opravdati posebnim

5 http://www.unizg.hr/fileadmin/rektorat/Novosti_press/Mediji/Priopcenja/SUZG_Uputa_o_ postupanju_11_03_2020.pdf, pristupljeno 3. IX. 2020. 
odlukama rektora odnosno dekana sastavnice Sveučilišta u Zagrebu. Zaposlenici i studenti Sveučilišta u Zagrebu koji boluju od kroničnih bolesti upućeni su na rad od kuće odnosno ostanak kod kuće uz dostavu odgovarajuće liječničke dokumentacije na rok od četrnaest dana od dana donošenja uputa. Rad od kuće za zaposlenike dogovorit će se s upravom Sveučilišta u Zagrebu, a ostanak studenata kod kuće dogovorit će se s dekanom sastavnice na kojoj studenti studiraju. U uputama je naznačeno i to da je Sveučilište u Zagrebu pripravno, u najkraćem mogućem roku u skladu s odlukama Stožera civilne zaštite Republike Hrvatske, uvesti nastavu na daljinu umjesto klasične kontaktne nastave za svih 66.000 studenata i 9500 nastavnika. Svim studentskim domovima naložena je povećana razina higijene i dezinficiranja prostora, a svim sastavnicama Sveučilišta u Zagrebu naloženo je da za sve korisnike osiguraju dovoljne količine dezinficijensa te podignu razinu i kvalitetu dezinficiranja prostora na sastavnicama. Pod utjecajem proglašene epidemije kao i zabrana mjera, uputa i preporuka koje su izdavala tijela civilne zaštite u Republici Hrvatskoj te Hrvatskog zavoda za javno zdravstvo, forma i sadržaj pravnog propisa koji je donesen 12. ožujka na Sveučilištu u Zagrebu, izvan je okvira uobičajene nomotehničke ali normativne prakse koju javne službe odnosno javne ustanove iz sustava visokog obrazovanja donose i primjenjuju u RH.

\section{PROPISI KOJI ODREĐUJU PRELAZAK NA OBLIK VISOKOŠKOLSKE NASTAVE, ,NA DALJINU““}

Dana 13. ožujka 2020. rektor Sveučilišta u Zagrebu donio je Odluku o promjeni u izvođenju oblika sveučilišne nastave na svim studijskim programima Sveučilišta u Zagrebu tako da će se nastava izvoditi na daljinu kako bi se svim studentima osigurala mogućnost studiranja od kuće. ${ }^{6}$ Rektor je u Odluci naložio da se, s obzirom na aktualno epidemiološko stanje, od ponedjeljka, 16. ožujka 2020., sveučilišna nastava na svim studijskim programima Sveučilišta u Zagrebu, izvodi kao nastava na daljinu kako bi studentima omogućila studiranje od kuće. Zaduženi su čelnici sastavnica Sveučilišta u Zagrebu (dekani fakulteta i akademija) da osiguraju dostupnost svih nastavnika prema studentima elektroničkim putem. Ključna odredba navedene Odluke jest ovlast koja je dana dekanima fakulteta i akademija da mogu odstupiti od uobičajene izvedbe nastave poštujući predviđene ishode učenja, studiranja, propisane studijskim programom i izvedbenim planovima svakog pojedinog studija. Nadalje, nalaže se nesmetan rad svih stručnih pomoćnih i tehničkih službi na Sveučilištu u Zagrebu i svim sastavnicama za čiju su provedbu zaduženi dekani. Propisano je očekivano trajanje mjera kojima je promijenjen oblik nastave u nastavu na daljinu na rok od četrnaest dana. Odlukom se upućuje na primjenu Uputa o postupanju od 12. ožujka 2020. Sveučilište u Zagrebu na isti je dan kad i Vlada RH donijelo odluku o izvođenju nastave na daljinu u skladu sa svojim

6 unizg.hr/fileadmin/rektorat/Novosti_press/Mediji/Priopcenja/2020-03-13_Odluka_Rektora.pdf, pristupljeno 4. IX. 2020 
ustavnim zakonskim i statutarnim ovlastima i nadležnostima. Od tog dana krenuo je poseban okvir za studiranje i sveučilišni život nezabilježen u dugogodišnjoj povijesti Sveučilišta u Zagrebu. Iako su zabrane, pravila, mjere, upute i preporuke kao specifični oblici forme pravnih propisa u doba pandemije odražavali svu težinu i opasnost izvanrednih prilika u kojima smo živjeli, donositelji pravnih propisa kojima se propisivao oblik nastave i sav (privid) sveučilišnog života, nisu smetnuli s uma esenciju sveučilišta i propisane uvjete i oblike izvedbe studija sa svim njegovim elementima.

Vlada Republike Hrvatske donijela je dana 13. ožujka 2020. Odluku o obustavi izvođenja nastave u visokim učilištima, srednjim školama te redovnog rada ustanova predškolskog odgoja i obrazovanja i o uspostavi nastave na daljinu (Narodne novine broj 29/2020 od 14. ožujka 2020.). Očito je kako je nositelj izvršne vlasti u Republici Hrvatskoj u skladu s ustavnim pravnim načelom razmjernosti zbog ugroze života i zdravlja pučanstva od zaraznih bolesti, a zbog proglašene epidemije na području Republike Hrvatske, ograničio ustavnu odredbu o autonomiji sveučilišta, te je ograničio ustavno pravo sveučilišta da odlučuje o svom ustroju i djelovanju u skladu s Ustavom RH i zakonom. Ranije spomenuti Zakon o znanstvenoj djelatnosti i visokom obrazovanju ${ }^{7}$ propisuje da sva visoka učilišta (sveučilišta, veleučilišta i visoke škole) imaju pravo na akademsku samoupravu koja obuhvaća utvrđivanje pravila studiranja i upisa studenata, izbor čelnika i nastavnika te upravljanje resursima kojima raspolažu visoka učilišta.

Za razliku od veleučilišta i visokih škola, sveučilišta imaju Ustavom RH zajamčeno pravo na autonomiju koja obuhvaća uređenje unutarnjeg ustroja u skladu sa zakonom, utvrđivanje obrazovnih, znanstvenih, umjetničkih i stručnih programa, financijsku autonomiju u skladu sa Zakonom o znanstvenoj djelatnosti i visokom obrazovanju, odlučivanje o prihvaćanju projekata i o međunarodnoj suradnji i ostale oblike autonomije u skladu sa Zakonom o znanstvenoj djelatnosti i visokom obrazovanju, sukladno ovom Zakonu.

Nositelj izvršne vlasti je na određeni način zbog načela razmjernosti radi sprečavanja ugroze zdravlja stanovništva suspendirao, odnosno ograničio ovlasti koje Ustav RH i Zakon o znanstvenoj djelatnosti i visokom obrazovanju daje sveučilištima u Republici Hrvatskoj kad su u pitanju akademska samouprava, odnosno utvrđivanje pravila studiranja i raspolaganje resursima kojima raspolažu visoka učilišta, te kad je u pitanju autonomija sveučilišta, odnosno utvrđivanje obrazovnih programa, te uređenje unutarnjeg ustroja sveučilišta. Naime, gotovo svi akreditirani, odnosno reakreditirani studijski programi na javnim sveučilištima u Republici Hrvatskoj u najvećem dijelu izvode se u klasičnoj, kontaktnoj nastavi uz mogućnost najviše do $20 \%$ izvedbe nastave na daljinu kroz jednu akademsku godinu, što je omogućeno predviđenim pravilima i postupcima akreditacije, odnosno reakreditacije sveučilišnih studijskih programa. Izmjena oblika i načina izvođenja nastave na nekom studijskom programu moguća je do $20 \%$ ukupnog

7 Prema Zakon o znanstvenoj djelatnosti i visokom obrazovanju (Narodne novine broj 123/03, 198/03, 105/04, 174/04, 02/07, 46/07, 45/09, 63/11, 94/13, 139/13, 101/14, 60/15, 131/17). 
fonda sati nastave a da se ponovno ne provodi akreditacija, odnosno reakreditacija sveučilišnog studijskog programa. ${ }^{8}$ Bar je tako postupano kroz sustav provjere i osiguravanja kvalitete u visokom obrazovanju koji provodi nadležna Agencija za znanost i visoko obrazovanje kroz pravni okvir propisan Zakonom o osiguravanju kvalitete u znanosti i visokom obrazovanju. ${ }^{9}$

Analizom pravnog propisa što ga je donijela Vlada RH, a odnosi se i na visoko obrazovanje, Odluka o obustavi izvođenja nastave u visokim učilištima, srednjim školama te redovnog rada ustanova predškolskog odgoja i obrazovanja i uspostavi nastave na daljinu od 13. ožujka 2020., ističem negativnu ocjenu u primjeni jedinstvenih nomotehničkih pravila kod izrade ovog općeg akta. Naime, u hrvatskoj, ali i u europskoj tradiciji, te u duhu i stilu hrvatskog književnog jezika jest da se izjavi i napiše kako se studira na visokom učilištu, a ne u visokom učilištu. Studirate na Pravnom fakultetu Sveučilišta u Zagrebu a ne studirate u Pravnom fakultetu u Zagrebu ili studirate na Sveučilištu u Splitu a ne u Sveučilištu u Splitu. Isto tako, kada se opisuje izvođenje sveučilišne nastave, onda se piše i govori na način kako se nastava izvodi na Sveučilištu u Splitu a ne u Sveučilištu u Splitu. Nije se poštovao duh i stil hrvatskog standardnog jezika kao jedno od načela i metoda u postupku izrade pravnih propisa u Republici Hrvatskoj. Slijedom navedenog u naslovu pravnog propisa nije trebalo pisati „obustava nastave u visokim učilištima“" već „obustava nastave na visokim učilištima“ s obzirom na to da se već morala donijeti mjera obustave klasičnog oblika nastave, tzv. kontaktne, fizičke, nastave. Skrećem pozornost na odredbu točke II. ove Odluke o obustavi izvođenja nastave u visokim učilištima, srednjim školama te redovnog rada ustanova predškolskog odgoja i obrazovanja i uspostavi nastave na daljinu prema kojoj se Zadužuje Ministarstvo znanosti i obrazovanja za koordinaciju poslova i dinamiku uspostave nastave na daljinu i za sva visoka učilišta. Ova odredba otvara prostor za temeljitu analizu ustavnopravnih stručnjaka o tome je li prekršena odredba o autonomiji sveučilišta i akademskoj samoupravi usprkos ustavnom načelu razmjernosti, odnosno stupnju ugroze zdravlja i zaštiti pučanstva. Je li bilo nužno da središnje tijelo državne uprave nadležno za poslove znanosti i obrazovanja koordinira poslove i dinamiku uspostave nastave na daljinu na visokim učilištima, napose na sveučilištima? Spomenuta odredba tim više začuđuje kad se uzme u obzir činjenica da je tadašnja čelnica i dužnosnica navedenog središnjeg tijela, ministrica, redovita sveučilišna profesorica i bivša prorektorica Sveučilišta u Zagrebu.

Sveučilište u Zagrebu, odnosno njegov rektor, donio je dana 16. ožujka 2020. pravni propis pod nazivom Preporuke za rad stručnih službi Sveučilišta u Zagrebu i svih njegovih sastavnica u vezi s pojavom koronavirusa. Riječ je o nizu preporuka i mjera kojima se preporučuje postupanje i način rada zaposlenika Sveučilišta u Zagrebu, organizacija i način rada stručnih službi te priprema dodatnih preventivnih mjera za slučaj potrebe i pogoršanja epidemiološke situacije. Svim zaposlenicima

8 Prema Pravilniku o sadržaju dopisnice te uvjetima za izdavanje dopusnice za obavljanje djelatnosti visokog obrazovanja, izvođenje studijskog programa i reakreditacije visokih učilišta (Narodne novine broj 24/10).

9 Narodne novine broj 45/2009. 
preporučuje se smanjivanje fizičkih kontakata i držanje fizičke udaljenosti međusobno prema drugim zaposlenicima tako da se pridržavaju razmaka od dva metra. Preporučuje se smanjenje radnih sastanaka između zaposlenika, a ako se sastanci moraju održati, preporučuje se održavanje sastanaka putem videoveze, telefonske veze i/ili elektroničkim putem. Ako se sastanak ipak mora održati, onda se preporučuje organizacija sastanka tako da se održi fizički razmak između sudionika sastanka od najmanje jedan i pol dužni metar. Upozoravaju se zaposlenici da imaju u vidu i neka vode računa o osobama s kojima su bili na udaljenosti manjoj od dva metra, odnosno vremenski dulje od petnaest minuta (,bliski kontakti“) u zadnjih 48 sati, odnosno da zapamte o kojim osobama je bila riječ bude li potrebno te podatke priopćiti epidemiolozima. Upućuju se zaposlenici da ostanu kod kuće u slučajevima pojave simptoma bolesti prouzročene koronavirusom, a ako su bili u kontaktu s osobom oboljelom od koronavirusa (vrućica i suhi kašalj) ili su se vratili iz područja u kojima je registrirana pojava koronavirusa unutar posljednjih četrnaest dana, sve zaposlenike treba informirati da imaju obavezu odmah obavijestiti nadležnu epidemiološku službu koja će im dati daljnje upute. Propisuje se da Sveučilište u Zagrebu i sastavnice moraju na vidljivim mjestima izvjesiti naputke za pranje ruku, održavanje osobne higijene i provedbu prvenstvenih mjera prema savjetima HZJZ-a. Letak s pravilima za postupanje mora biti zorno izložen na vidljivim mjestima. Sveučilište u Zagrebu i njegove sastavnice moraju osigurati dovoljne količine sapuna i papirnatih ubrusa za svoje djelatnike. Dezinfekcijska sredstva trebaju biti na raspolaganju svim djelatnicima, pogotovo onima koji imaju kontakt s građanima, te djelatnike treba poticati da ih redovito koriste. Radni prostori Sveučilišta u Zagrebu i njegovih fakulteta i akademija trebaju se čistiti prema protokolu za borbu protiv koronavirusa koji propisuje HZJZ. Pravila za postupanje trebaju biti zorno izložena na vidljivim mjestima. Istini za volju, ovdje treba priznati da su mjere izvedene iz uputa i preporuka koje je izradilo Ministarstvo uprave i pravosuđa RH za rad svih državnih službenika i namještenika u tijelima državne uprave RH. Za restorane Studentskog centra preporučeno je da se moraju organizirati tako da su djelatnici leđima okrenuti jedni od drugih na uzastopno postavljenim stolovima te da je između dvije osobe ostavljeno po jedno slobodno mjesto. Osoblje koje hranu servira treba to učiniti noseći zaštitne maske i rukavice. U preporukama se navodi da je sadašnja epidemiološka situacija u Republici Hrvatskoj u kontroliranim uvjetima te da je dužnost Sveučilišta u Zagrebu i njegovih sastavnica da budu pripravni na sve scenarije rada i djelovanja te da imaju na vrijeme razrađene procedure za rad u slučaju potrebe za primjenom drastičnijih mjera i njihovom brzom provedbom. U tu svrhu preventivno se preporučuju pripreme mjera za komunikaciju tako da je kadrovska služba Sveučilišta u Zagrebu, odnosno njegove sastavnice, dužna prikupiti brojeve mobitela ili/i kućne telefonske brojeve i adrese svih zaposlenika. Sveučilište u Zagrebu i njegove sastavnice trebaju imenovati „koordinatore COVID-19" kojima se zaposlenici mogu obratiti s pitanjima, a koji će također nadgledati i olakšavati izvršavanje preporuka iz tog dokumenta. Kriteriji rizičnosti i nužnosti jako su bitni. Voditelj središnje službe na Sveučilištu u Zagrebu i voditelji službi/ureda na sastavnicama moraju sastaviti listu djelatnika, prema kriterijima 
rizičnosti i nužnosti. Analizom sadržaja akta Preporuke za rad stručnih službi Sveučilišta u Zagrebu i svih njegovih sastavnica u vezi s pojavom koronavirusa, potpuno je jasno da je Sveučilište u Zagrebu preuzelo dio uputa i preporuka koje je donijelo Ministarstvo uprave RH kao dokument pod nazivom „Upute za rad tijela državne uprave u vezi s pojavom bolesti prouzročene virusom od 19. ožujka $2020 .{ }^{10}$ Normativnu djelatnost Ministarstva uprave RH, koja je rezultirala jasnim i nedvosmislenim uputama za rad državnih službenika i namještenika, što se iskoristilo u preporukama koje je donijelo SuZ za rad službenika na stručnim općim tehničkim i pomoćnim poslovima, pokazuje zavidnu razinu kvalitete nomotehničke izrade uputa što ih je donijelo Ministarstvo uprave RH.

Već 19. ožujka 2020. Vlada RH izmijenila je i dopunila spomenutu Odluku o obustavi izvođenja nastave u visokim učilištima, srednjim školama te redovnog rada ustanova predškolskog odgoja i obrazovanja i uspostavi nastave na daljinu i donijela je Odluku o izmjeni Odluke o obustavi izvođenja nastave u visokim učilištima, srednjim školama te redovnog rada ustanova predškolskog odgoja i obrazovanja i o uspostavi nastave na daljinu od 13. ožujka 2020. (Narodne novine broj 32/2020). ${ }^{11}$ Izmijenjenom i dopunjenom Odlukom propisana je dužnost čelnicima tijela visokih učilišta organizirati rad ustanova u suradnji s Ministarstvom znanosti i obrazovanja tako da se nesmetano odvija nastava na daljinu. Ovdje je izvršna vlast ipak dosljedno primijenila načelo razmjernosti,(o)stavljajući ipak tijelima i čelnicima sveučilišta dužnost i ovlast da organiziraju sveučilišnu nastavu na daljinu. Stožer civilne zaštite RH donio je dana 19. ožujka 2020. Odluku o mjerama ograničavanja društvenih okupljanja, rada u trgovini, uslužnih djelatnosti i održavanja sportskih i kulturnih događaja ${ }^{12}$ kojima je naložena mjera fizičke udaljenosti s razmakom od dva dužna metra u zatvorenom prostoru i jednog metra na otvorenom prostoru. Nadalje propisana je i zabrana okupljanja više od pet osoba na jednom mjestu. Također je poslodavcima naložena obveza organizacije rada od kuće gdje je moguće, otkazivanje sastanka i organizacija telekonferencija, virtualno i na daljinu. Navedena Odluka Stožera civilne zaštite donesena je temeljem odredbi Zakona o sustavu civilne zaštite i na odgovarajući način se primjenjuje i na sve javne ustanove u Republici Hrvatskoj, odnosno sve poslodavce u Republici Hrvatskoj. Zabranjeno je održavanje svih javnih događaja i okupljanja s više od pet osoba na jednom mjestu. Sva sveučilišta, pa tako i Sveučilište u Zagrebu, bila su dužna provoditi navedenu Odluku Stožera civilne zaštite RH, te time prilagoditi svoju djelatnost i odlukama Stožera civilne zaštite RH.

Rektor Sveučilišta u Zagrebu donio je dana 30. ožujka 2020. preporuke za način polaganja ispita, ispitne rokove i mjerila ispitivanja u izvanrednim okolnostima na

10 https://uprava.gov.hr/UserDocsImages/Dokumenti/Uputa\%20za\%20rad\%20tijela\%20dr\%C5\% BEavne $\% 20$ uprave $\% 20$ u $\% 20$ vezi $\% 20$ s $\% 20$ pojavom $\% 20$ bolesti\%20COVID-19\%20uzrokovane $\% 20$ virusom\%20SARS-CoV-2,\%20dostavlja\%20se.pdf, pristupljeno 8. IX. 2020.

11 https://narodne-novine.nn.hr/clanci/sluzbeni/2020_03_32_711.html, pristupljeno 9. IX. 2020.

12 https://civilna-zastita.gov.hr/UserDocsImages/CIVILNA\%20ZA\%C5\%A0TITA/PDF_ZA\%20 WEB/Odluka\%20-\%20mjere\%20ograni\%C4\%8Davanja\%20dru\%C5\%A1tvenih\%20okupljanja, \%20 rada\%20trgovina.pdf, pristupljeno 10. IX. 2020. 
Sveučilištu u Zagrebu. U uvodnom dijelu naznačeno je da je Sveučilište u Zagrebu prikupilo podatke o tome kako se provjeravaju ishodi učenja prema predviđenom studijskom programu i planu izvođenja nastave na studijskom programu u normalnim okolnostima prema akreditaciji koja je provedena. Iz prikupljenih podataka ukazala se velika potreba donošenja pravila o vrednovanju, odnosno načinu provjere predviđenih ishoda učenja u okolnostima proglašene epidemije odnosno pandemije prouzročene bolešću COVID-19. Rektor ističe da je analizom dostavljenih podataka utvrđeno kako se provjera ishoda učenja na razini svakog kolegija na sveučilišnom studijskom programu razlikuje od kolegija do kolegija, ne samo među pojedinim fakultetima i akademijama, nego i unutar istog fakulteta i/ili akademije. Utvrđeno je i da fakulteti i akademije koriste razne platforme e-učenja za provjeru onih ishoda učenja koja se mogu tako provjeravati, putem različitih računalnih sustava odnosno uspostavom drugačijih komunikacijskih sustava između nastavnika i studenata. Rektor je konstatirao kako nastava na daljinu nije redoviti oblik sveučilišne nastave, nego je nužda i jedini mogući model u danim okolnostima. U skladu s Odlukom o izvođenju nastave na daljinu od 13. ožujka 2020. dekanima fakulteta i akademija ostavljena je mogućnost definiranja odstupanja od uobičajene izvedbe nastave, ali poštujući predviđene ishode učenja prema akreditiranom sveučilišnom studijskom programu. Preporuke za način polaganja ispita, ispitne rokove i mjerila ispitivanja u izvanrednim okolnostima na Sveučilištu u Zagrebu obuhvaćaju mjere kojima se propisuje da način provedbe programa kolegija i prilagodba specifičnostima takvog postupka učenja, kao i sami ispiti, u najvećoj mogućoj mjeri moraju odgovarati predviđenim ishodima učenja u akreditiranim sveučilišnim studijskim programima. Sveučilišnim nastavnicima i dekanima fakulteta i akademija nalaže se da vode računa o tome da se opterećenje studenata i organizacija sveučilišne nastave u ovim izvanrednim okolnostima temelji na radnom opterećenju studenta od četrdeset sati tjedno, u što se uračunava sama nastava, terenski rad, praktične vježbe i drugi oblici nastave kao i vrijeme potrebno za pripremu studenta, te da opterećenje studenta tijekom cijelog studija treba biti ravnomjerno. Ukupne tjedne obveze studenta u nastavi najviše mogu iznositi u preddiplomskom studiju dvadesetšest sati, u diplomskom studiju dvadeset sati te u poslijediplomskom studiju dvanaest sati tjedne nastave. Čelnicima fakulteta i akademija nalaže se uvođenje internog sustava praćenja realizacije izvođenja sveučilišne nastave na daljinu u odnosu na sveučilišne nastavnike i studente te provođenje kontrole kvalitete održane sveučilišne nastave na daljinu. Također kriteriji i metode vrednovanja u izvanrednim okolnostima moraju biti pravodobno objavljeni i javno dostupni svim studentima. Propisano je da je za bilo koju vrstu provjere ishoda učenja, koja se održava na daljinu, potrebno nekoliko dana ranije organizirati probni kolokvij ili kratki test koji je tehnički implementiran na isti način kao i stvarna provjera znanja, odnosno kolokvij, kako bi se studenti upoznali s drugačijim načinom održavanja provjere znanja, odnosno kolokvija. Između ostalog, propisuje se i to da je potrebno posebnu pozornost obratiti na izvođenje sveučilišne nastave na daljinu, te tako ostvariti što je više moguće plana izvođenja sveučilišnog studijskog programa i da će se po potrebi razmotriti pomicanje ispitnih rokova, kao i uvođenje dodatnih ispitnih rokova. $\mathrm{U}$ 
skladu s daljnjim razvojem epidemiološke situacije, organizirat će se nadoknade za one kolegije sveučilišnog studija koje nije moguće izvoditi na daljinu, kako bi studenti stekli potrebne vještine i znanja prema predviđenim ishodima učenja. Predviđeno je i to da će se nastava pojedinih kolegija možebitno organizirati i u kraćem vremenu kao blok-nastava, ako epidemiološke prilike budu dopuštale fizičko, kontaktno izvođenje sveučilišne nastave. U Preporukama za način polaganja ispita, ispitne rokove i mjerila ispitivanja u izvanrednim okolnostima na Sveučilištu u Zagrebu konstatirano je da, ako se epidemiološka situacija ne popravi do kraja ljetnog semestra do razine koja bi omogućavala održavanje ispita na uobičajen način, za kolegije za koje je to moguće potrebno je organizirati provjeru ishoda učenja na alternativan način. Za ostale kolegije za koje to nije moguće, ovisno o daljnjem razvoju situacije, Sveučilište u Zagrebu, u suradnji sa svojim fakultetima i akademijama, razmotrit će kako pristupiti rješenju možebitnih problema u izvođenju nastave. Ponovno je naglašeno da su fakulteti i akademije dužni samostalno definirati konačne oblike provjere ishoda učenja. Posljednje konstatacije i preporuke dobile su na aktualnosti u situaciji kad se više od polovine sveučilišne nastave na određenom broju sastavnica na Sveučilištu u Zagrebu, ali i na nekim drugim javnim sveučilištima, izvode kao sveučilišna nastava na daljinu usprkos i unatoč činjenici da su preporuke i mjere Hrvatskog zavoda za javno zdravstvo bile u smjeru održavanja klasičnog oblika sveučilišne nastave odnosno kontaktne, fizičke nastave. Kao posljednja rektorova preporuka naznačen je apel na susretljivost, tolerantnost, razumijevanje i fleksibilnost $\mathrm{u}$ danim okolnostima.

Djelatnost i poslovanje Sveučilišta u Zagrebu kroz razdoblje od ožujka do srpnja 2020. obilježio je, uz pandemiju, prije svega razorni potres koji je pogodio Grad Zagreb i njegovu okolicu 22. ožujka 2020. Nije potrebno posebno spominjati u kojim okolnostima je djelovalo Sveučilište u Zagrebu gdje je raščišćavanje materijala i konzerviranje postojećeg stanja na građevinskim objektima uz primjenu epidemioloških uputa, mjera i preporuka bilo prioritet kako bi se nesmetano odvijala visokoškolska nastavna i znanstvena djelatnost.

Međutim, rektor Sveučilišta u Zagrebu uputio je 6. svibnja 2020. svim sastavnicama (fakultetima i akademijama) Sveučilišta u Zagrebu Preporuke za preddiplomsku, diplomsku i poslijediplomsku nastavu tijekom pandemije. Polazeći od pretpostavke da svaki boravak u objektima i infrastrukturi na Sveučilištu u Zagrebu, uključujući putovanje na fakultet i akademiju i Sveučilište i nazad, može predstavljati povećani rizik za zarazu u odnosu na boravak u obiteljskom domu, odnosno kućanstvu, preporučeno je i upućeno da se sve aktivnosti sveučilišne nastave, koliko je god moguće, provode e-komunikacijom i telefonom (nastava i polaganje ispita na daljinu), te da se izbjegavaju susreti uživo, a pogotovo grupiranja studenata/sveučilišnih nastavnika/zaposlenika. Preporučen je ostanak kod kuće medicinski kompromitiranim osobama, a studentima/sveučilišnim nastavnicima/ zaposlenicima i drugim osobama da ne ulaze u vanjske prostore (dvorište, vrt, igralište) i unutarnje prostore Sveučilišta/sastavnice ako imaju simptome koji upućuju na sumnju zaraze ili koji su pod rizikom da su mogli biti u kontaktu s osobama pozitivnim na COVID-19 ili su pod sumnjom da bi mogli biti zaraženi, 
ili su u samoizolaciji. Riječ je o još jednom u nizu propisa kojim se osigurava zaštita života i zdravlja svih subjekata sveučilišne zajednice, a isto tako osigurava se kontinuitet sveučilišne nastave, ali u drugom obliku. Nadalje, organizacija dijelova nastave ili ispita te drugih studentskih obveza koje se nikako ne mogu provesti na daljinu, rektor upućuje da se provede tako da potreban (neizbježan) boravak na Sveučilištu/sastavnici bude organiziran tako da se osigura u što većoj mjeri socijalna distanca (fizička udaljenost), kao i pojačana higijena ruku i higijena prostora. Potiču se sastavnice Sveučilišta u Zagrebu da za studente organiziraju dostupnost nužnoj računalnoj opremi sukladno mogućnostima Sveučilišta/sastavnice. Rektor je zadužio dekane sastavnica Sveučilišta u Zagrebu za procjenu, izbor i provedbu mjera na svojim sastavnicama kako bi se u skladu s propisanim i akreditiranim sveučilišnim studijskim programima provele sve obveze na svim razinama studija za studente/ sveučilišne nastavnike/zaposlenike. Preporučene su mjere fizičke udaljenosti između osoba koje borave na Sveučilištu u Zagrebu i njegovim sastavnicama tako da se kod ulaska i izlaska u objekte Sveučilišta/sastavnica, kretanja po objektima, te boravka u objektima, drži razmak od najmanje dva metra u odnosu na druge osobe. Prostor u kojem se boravi (provodi dio nastave i/ili izvršenja studentskih obveza) treba biti što veći i prozračan te $u$ istom prostoru ne smije boraviti više od deset osoba $\mathrm{u}$ isto vrijeme. Boravak na Sveučilištu/sastavnicama potrebno je organizirati tako da se rad odvija u malim skupinama studenata/sveučilišnih nastavnika/zaposlenika (ukupno do deset osoba). Nadalje, student/sveučilišni nastavnik/zaposlenik se u održavanju nastave vremenski ne preklapaju tako da se prostor prije ulaska sljedeće grupe studenata/nastavnika može odgovarajuće prozračiti i dezinficirati. Svaka skupina studenata/sveučilišnih nastavnika/zaposlenika održava nastavu uvijek u istom, za njih predviđenom prostoru. Radna mjesta sveučilišnih nastavnika/ zaposlenika moraju biti udaljena toliko da studenti zadržavaju osobni prostor od dva metra. Ulazak u knjižnicu Sveučilišta/sastavnice organizirat će Sveučilište/ sastavnica ovisno o veličini i radnim mjestima, a preporuke za organizaciju prostora za izvršavanje studentskih obveza odnosno za organizaciju rada na radnim mjestima i boravka osoba u objektima Sveučilišta/sastavnice. Preporučene su značajke prostora u kojem boravi jedna skupina studenata/nastavnika tako da se prostori moraju redovito provjetravati i dezinficirati, a posebnu pozornost treba posvetiti higijeni i dezinfekciji toaleta. Istovremeni prolazak kroz zajedničke prostore treba izbjegavati i minimizirati, tako da se uvede stanka između održavanja sveučilišne nastave te da se uračuna vrijeme čišćenja prostora.

U Preporukama je naznačena i jedna zabrana prema kojoj su do daljnjeg zabranjeni svi posjeti objektima Sveučilišta/sastavnica poput primjerice javnih tribina, seminara, sastanaka s brojem sudionika većim od deset osoba, izvannastavne aktivnosti i sl. Preporučena je organizacija rada u smjenama. Na Sveučilištu/sastavnici treba biti najmanji mogući broj studenata/sveučilišnih nastavnika/zaposlenika u isto vrijeme. Rektor preporučuje poticanje rada od kuće te preporučuje da se ne dozvoljava ulazak zaposlenicima koji nisu raspoređeni na posao na radnom mjestu. Preporučeno je i da se svakodnevno kod dolaska i odlaska sa Sveučilišta/sastavnice, studentima/sveučilišnim nastavnicima/zaposlenicima 
mjeri tjelesna temperatura beskontaktnim toplomjerom te se utvrđuje postoje li ikakvi simptomi ili znakovi bolesti. Kod osobe s povišenom temperaturom $\left(37,2^{\circ}\right.$ $\mathrm{C}$ i više) mjeri se temperatura i standardnim toplomjerom te na temelju tog rezultata poduzimaju propisani epidemiološki koraci. Naložena je posebna evidencijska knjiga o vrijednostima izmjerene tjelesne temperature i o eventualnom postojanju respiratornih simptoma. Preporukama su obvezani studenti/sveučilišni nastavnici/ zaposlenici mjeriti temperaturu prije svakog dolaska na Sveučilište/sastavnicu te u slučaju povećane tjelesne temperature javiti se telefonom nadređenoj osobi i izabranom liječniku obiteljske medicine. U slučaju pojave povišene tjelesne temperature i/ili respiratornih simptoma potrebno je odmah napustiti Sveučilište/ sastavnicu, javiti se nadređenoj osobi i svojem izabranom liječniku obiteljske medicine. U slučaju saznanja za mogućeg prenositelja/mogući izvor infekcije svaki student/sveučilišni nastavnik/zaposlenik dužan je odmah obavijestiti nadređenu osobu. U slučaju nemogućnosti organizacije posla zbog većeg broja zaposlenika koji su u samoizolaciji, dekani sastavnica Sveučilišta u Zagrebu u koordinaciji s rektorom Sveučilišta u Zagrebu mogu preraspodijeliti zaposlenike drugih sastavnica Sveučilišta u Zagrebu, a kako bi se osigurala kontinuirana sveučilišna nastava. Rektor je propisao i da svaki zadatak dekan sastavnice Sveučilišta u Zagrebu treba dodijeliti odgovornoj osobi koja vodi dnevnu pisanu evidenciju o provođenju gore navedenog. U završnim preporukama naglašeno je kako ove preporuke ne isključuju provođenje drugih preporuka sukladno aktualnoj i promjenjivoj epidemiološkoj situaciji, što pretpostavlja kontinuirano praćenje rada Kriznog stožera Sveučilišta u Zagrebu te Stožera civilne zaštite RH. Kao važna napomena, na kraju Preporuka za preddiplomsku, diplomsku i poslijediplomsku nastavu tijekom pandemije, propisano je da se preporuke odnose na sastavnice Sveučilišta u Zagrebu koje nisu pogođene posljedicama potresa na području Grada Zagreba te čija znanstvena i nastavna infrastruktura nije privremeno $\mathrm{i} / \mathrm{ili}$ trajno neupotrebljiva.

Vlada RH donijela je 8. svibnja 2020. Odluku o načinu izvođenja nastave u osnovnim i srednjim školama kao i na visokim učilištima te obavljanju redovnog rada ustanova u području predškolskog odgoja i obrazovanja (Narodne novine, broj 55/2020). ${ }^{13}$ Iz samog naziva ovog novog općeg akta Vlade RH koji se između ostalog odnosi i na način izvođenja nastave na visokim učilištima, vidljivo je nomotehničko poboljšanje kod izrade naslova pravnog propisa. Kako su se popravljale epidemiološke prilike, tako su i dopušteni pojedini oblici klasične kontaktne sveučilišne nastave Odlukom Vlade RH. U točki III. Odluke propisuje se da se za polaznike visokih učilišta nastava organizira kao nastava na daljinu te se omogućava održavanje laboratorijskih, umjetničkih i kliničkih vježbi te praktični rad u malim grupama u visokom obrazovanju kao kontaktna fizička nastava. I nadalje se zadužuje MZO RH za koordinaciju poslova u svezi s izvođenjem navedenih oblika nastave na visokim učilištima. Propisano je i da stupanjem na snagu ove Odluke, Odluka o obustavi izvođenja nastave u visokim učilištima, srednjim i osnovnim

13 https://narodne-novine.nn.hr/clanci/sluzbeni/2020_05_55_1094.html, pristupljeno 13. IX. 2020. 
školama te redovnog rada ustanova predškolskog odgoja i obrazovanja i uspostavi nastave na daljinu (Narodne novine, broj 29/20 i 32/20) prestaje važiti.

Značajno je spomenuti i organizaciju provedbe ispita državne mature koja u Republici Hrvatskoj ima dvojaki karakter; osim što predstavlja završnost srednjoškolskog obrazovanja, ujedno je i prijemni opći ispit za upis na sveučilišta. Javna sveučilišta na čelu sa sveučilištem u Zagrebu inzistirala su na provedbi općih i izbornih predmeta na ispitima Državne mature slijedom čega je Hrvatski zavod za javno zdravstvo u suradnji s Nacionalnim centrom za vanjsko vrednovanje obrazovanja i Ministarstvom znanosti i obrazovanja izradio mjere za pristupanje ispitima i drugim provjerama znanja na sveučilištima za dodatnu provjeru pri upisu na sveučilišta nakon polaganja državne mature te su dana 27. svibnja 2020. objavljene Upute za provedbu državne mature tijekom epidemije koronavirusa za ljetni rok lipanj 2020. godine. ${ }^{14}$ Epidemiološke upute za provedbu državne mature na prvom ljetnom roku u 2020. značajne su i za sva javna sveučilišta, jer se provedbom ispita državne mature provodi i provjera znanja pristupnika za upis na sveučilišni studij, a za što se ugovorom obvezao nacionalni centar za vanjsko vrednovanje obrazovanja te je ispit iz državne mature zamijenio razredbene, prijamne ispite na hrvatskim javnim sveučilištima.

\section{POSTUPCI IZBORA ČELNIKA VISOKIH UČILIŠTA I NAČIN DONOŠENJA ODLUKA KOLEKTIVNIH TIJELA NA VISOKIM UČILIŠTIMA U DOBA PANDEMIJE COVID-A 19}

Tijekom razdoblja pandemije pojavio se cijeli niz dvojbi i nepoznanica $u$ pogledu organizacije rada pojedinih kolektivnih tijela unutar upravljačke strukture Sveučilišta u Zagrebu, ali i oko provedbe postupka izbora čelnika/dekana pojedinih sastavnica Sveučilišta u Zagrebu s obzirom na činjenicu da Statut Sveučilišta u Zagrebu ${ }^{15}$ kao temeljni opći akt, ali i statuti pojedinih sastavnica (fakulteta i akademija), predviđaju složenu i dugotrajnu proceduru kandidiranja, predstavljanja i samoizbora dekana/čelnika fakulteta i akademije. Statut Sveučilišta u Zagrebu, ali i temeljni opći akti (statuti) sastavnica Sveučilišta u Zagrebu, propisuju obvezu tajnog glasovanja kao način izbora dekana, čelnika sastavnice Sveučilišta. S tim u svezi Odbor za statutarna pitanja Sveučilišta u Zagrebu, kao savjetodavno tijelo Senata i Rektorskog kolegija Sveučilišta u Zagrebu koje daje pravno mišljenje u svezi s prijeporima i nedoumicama oko primjene pojedinih odredbi Statuta Sveučilišta u Zagrebu, zaprimio je upit za davanje pravnog mišljenja u primjeni dijela odredbe članka 42. stavka 2. Statuta Sveučilišta u Zagrebu u odnosu na dio odredbe članka

14 https://www.hzjz.hr/wp-content/uploads/2020/03/Drzavna_matura_upute_27_05.pdf, pristupljeno 14. IX. 2020.

15 http://www.unizg.hr/fileadmin/rektorat/O_Sveucilistu/Dokumenti_javnost/Dokumenti/Strateski_ dokumenti/statut/Potpisani_procisceni_tekst_Statuta_Sveucilista_9.10.2017..pdf, pristupljeno 14. IX. 2020. 
42. stavka 4. Statuta Sveučilišta u Zagrebu, ${ }^{16}$ a s obzirom na status pokrenutih postupaka izbora dekana koji nisu završeni „najkasnije četiri mjeseca prije nastupa na dužnost" te na vremensko određenje od kojega, u slučaju da dekan nije izabran četiri mjeseca prije nastupa na dužnost, teče rok od 30 dana u kojem stručno vijeće treba predložiti osobu koja ispunjava propisane uvjete kao obnašatelja dužnosti do izbora novog dekana.

Rektorski kolegij Sveučilišta u Zagrebu zatražio je od Odbora za statutarna pitanja i pravno mišljenje o načinu provedbe odredbi općih akata sastavnica Sveučilišta u Zagrebu koje propisuju tajno glasovanje kao način odlučivanja kolektivnih tijela na Sveučilištu u Zagrebu i na njegovim sastavnicama s obzirom na odluke, upute, mjere i preporuke koje su donijeli rektor Sveučilišta u Zagrebu, Hrvatski zavod za javno zdravstvo i Stožer civilne zaštite RH u svezi s pandemijom. Na temelju pravnog mišljenja Odbora za statutarna pitanja, rektor Sveučilišta u Zagrebu kao čelnik i zakonski zastupnik Sveučilišta u Zagrebu s pravima i dužnostima ravnatelja javne ustanove, donio je pravni propis pod nazivom Upute o postupanju u postupcima izbora dekana i postupcima tajnog glasovanja koji sadrži 8 točaka: ${ }^{17}$

1. Postupak izbora dekana na svim sastavnicama Sveučilišta u Zagrebu mora se dovršiti najkasnije četiri mjeseca prije isteka mandata sadašnjem dekanu. Dekan sastavnice smatra se izabranim u redovitom postupku donošenjem odluke stručnog vijeća (fakultetskog vijeća ili vijeća akademije) o izboru dekana zaključno sa 31. svibnja tekuće akademske godine.

2. Odredba članka 59. stavka 2. točke 14. Zakona o znanstvenoj djelatnosti i visokom obrazovanju (Narodne novine broj 123/03, 198/03, 105/04, 174/04, 02/07, 46/07, 45/09, 63/11, 94/13, 139/13, 101/14, 60/15, 131/17) temeljem koje Senat potvrđuje izbor čelnika sastavnice Sveučilišta u Zagrebu može se primijeniti i nakon proteka roka od 1. lipnja tekuće akademske godine, odnosno nakon proteka roka po kojem postupak izbora na mjesto dekana kojem istječe mandat mora završiti najkasnije četiri mjeseca prije nastupa na dužnost.

3. U slučaju da dekan sastavnice nije izabran do 31. svibnja tekuće godine, rok od 30 dana u kojem stručno vijeće sastavnice (fakultetsko vijeće ili vijeće akademije)

16 Članak 42. stavak 4. Statuta Sveučilišta u Zagrebu glasi: „Postupak izbora dekana započinje pozivom stručnog vijeća za podnošenje prijedloga. Predloženici dostavljaju stručni životopis i program rada koji usmeno izlažu pred stručnim vijećem. Prijedlozi koji dobiju suglasnost stručnog vijeća upućuju se Senatu koji mora, na prijedlog rektora, u roku od mjesec dana odlučiti o davanju suglasnosti na uredno podneseni zahtjev. Odluka rektora i Senata kojom se uskraćuje suglasnost mora biti obrazložena. Stručno vijeće tajnim glasovanjem bira dekana među predloženicima za koje je Senat dao suglasnost, po postupku utvrđenom statutom fakulteta. Za dekana je izabran predloženik koji u konačnom glasovanju dobije natpolovičnu većinu ukupnog sastava stručnog vijeća. Postupak izbora na mjesto dekana kojem istječe mandat mora završiti najkasnije četiri mjeseca prije nastupa na dužnost.“

Članak 42. stavak 4. Statuta Sveučilišta u Zagrebu glasi: „Ako se novi dekan ne izabere do isteka ranijeg mandata, stručno vijeće će u roku od 30 dana predložiti Senatu osobu koja ispunjava propisane uvjete kao obnašatelja dužnosti do izbora dekana. Senat u roku od 30 dana imenuje obnašatelja dužnosti nakon pribavljene suglasnosti rektora.“

17 Uputa o postupanju u postupcima izbora dekana i postupcima tajnog glasovanja upućena je svim sastavnicama Sveučilišta u Zagrebu dana 25. svibnja 2020. (Klasa: 602-04/20-08/1; Urbroj:380-022/331-20-3). 
treba predložiti osobu koja ispunjava uvjete za obnašatelja dužnosti do izbora novog dekana, počinje teći od 1. lipnja tekuće godine.

4. Ako stručno vijeće sastavnice u navedenom roku ne dostavi prijedlog osobe koja ispunjava uvjete za obnašatelja dužnosti dekana do izbora novog dekana, rektor će u roku od daljnjih trideset dana, počevši od 1. srpnja tekuće godine, predložiti Senatu obnašatelja dužnosti dekana.

5. Obnašatelj dužnosti dekana kojeg na prijedlog stručnog vijeća ili na prijedlog rektora imenuje Senat, stupa na dužnost 1. listopada tekuće godine.

6. Tajno glasovanje, kao način odlučivanja, na sjednici kolektivnog tijela na Sveučilištu u Zagrebu ili na njegovim sastavnicama podrazumijeva fizičku, odnosno kontaktnu sjednicu kolektivnog tijela, te može biti održano samo tako da se provodi na glasačkim listićima uz primjenu odnosno poštovanje epidemiološkog okvira propisanog na razini Republike Hrvatske te Sveučilišta u Zagrebu. Iznimno, tajno glasovanje kolektivnog tijela može se održati i elektroničkim putem, tako da nitko, pa ni administrator elektroničkog sustava (tzv. sistem inženjer) nema mogućnost neposrednog uvida u tijek i rezultate tajnog glasovanja kao načina odlučivanja kolektivnog tijela.

7. Odluke koje su tijela eventualno donijela u postupku tajnog glasovanja, a koje nije obavljeno na navedeni fizički ili kontaktni način, odnosno, u slučaju elektroničkog provođenja glasovanja, tako da nitko pa ni administrator elektroničkog sustava (tzv. sistem inženjer) nije imao mogućnost neposrednog uvida u tijek i rezultate tajnog glasovanja, ne mogu se prema važećim propisima smatrati valjanim, pa je u tim slučajevima potrebno ponoviti postupak glasovanja. 
Ivica Šušak, dipl. iur.: Izrada pravnih propisa u sustavu visokog obrazovanja u vrijeme pandemije COVID-a 19 Zbornik radova Pravnog fakulteta u Splitu, god. 58, 2/2021, str. 501-524

\section{Mišljenje/stajalište Odbora za statutarna pitanja Sveučilišta u Zagrebu od 20. svibnja 2020. godine dostavlja se u prilogu kao sastavni dio Uputa. ${ }^{18}$}

18 Pravno stajalište o primjeni dijela odredbe članka 42. stavka 2. Statuta Sveučilišta u Zagrebu u odnosu na dio odredbe članka 42. stavka 4. Statuta Sveučilišta u Zagrebu: a) Iz dijela članka 42. stavka 2. Statuta Sveučilišta u Zagrebu koji glasi: „postupak izbora na mjesto dekana kojem istječe mandat mora završiti najkasnije četiri mjeseca prije nastupa na dužnost “, jasno proizlazi da se postupak izbora dekana mora dovršiti najkasnije četiri mjeseca prije isteka mandata sadašnjem dekanu. Dekan sastavnice smatra se izabranim u redovitom postupku donošenjem odluke stručnog vijeća o izboru dekana zaključno s 31 . svibnja tekuće akademske godine, a koja odluka ima konstitutivan karakter. S tim u svezi, odredba članka 59. stavka 2. točke 14. Zakona o znanstvenoj djelatnosti i visokom obrazovanju, a temeljem koje Senat potvrđuje izbor čelnika sastavnice Sveučilišta u Zagrebu može se primijeniti i nakon proteka roka od 1. lipnja tekuće akademske godine odnosno nakon proteka roka po kojem postupak izbora na mjesto dekana kojem istječe mandat mora završiti najkasnije četiri mjeseca prije nastupa na dužnost; b) Clankom 42. stavkom 4. Statuta Sveučilišta u Zagrebu propisano je: „Ako se novi dekan ne izabere do isteka ranijeg mandata, stručno vijeće će u roku od 30 dana predložiti Senatu osobu koja ispunjava propisane uvjete kao obnašatelja dužnosti do izbora dekana. " Iz toga nedvosmisleno proizlazi pravno stajalište po kojem od 1. lipnja tekuće akademske godine počinje teći rok od 30 dana u kojem stručno vijeće sastavnice treba predložiti osobu koja ispunjava uvjete za obnašatelja dužnosti do izbora novog dekana. Kao prilog navedenom pravnom stajalištu ide i odredba članka 42. stavka 5. Statuta Sveučilišta u Zagrebu koja propisuje: „U slučaju da stručno vijeće u propisanom roku ne dostavi prijedlog, obnašatelja dužnosti dekana imenovat će Senat na prijedlog rektora." Ovdje se misli na rok od 30 dana u kojem stručno vijeće treba dostaviti prijedlog za obnašatelja dužnosti dekana. Ako stručno vijeće ne dostavi prijedlog stručnog vijeća u roku od 30 dana (počevši od 1. lipnja tekuće akademske godine), onda se primjenjuje citirana odredba da „će obnašatelja dužnosti dekana imenovati Senat na prijedlog rektora“. Analognom primjenom odredbi o rokovima iz članka 42. stavka 4. Statuta Sveučilišta rektor bi svoj prijedlog Senatu trebao podnijeti u roku od 30 dana koji teče od 1. srpnja tekuće godine. Obnašatelj dužnosti dekana kojeg na prijedlog rektora imenuje Senat stupa na dužnost 1. listopada tekuće godine. Pravno stajalište o načinu provedbe odredbi općih akata Sveučilišta u Zagrebu i sastavnica Sveučilišta u Zagrebu koje u određenim slučajevima propisuju tajno glasovanje kao način odlučivanja kolektivnih tijela na Sveučilištu u Zagrebu i na njegovim sastavnicama s obzirom na epidemiološki okvir koji se primjenjuje u Republici Hrvatskoj i na Sveučilištu u Zagrebu. Odbor za statutarna pitanja usvojio je zaključak kojim se utvrđuje pravno stajalište da tajno glasovanje, kada je to statutom propisani način odlučivanja, na sjednici kolektivnog tijela na Sveučilištu u Zagrebu ili na njegovim sastavnicama, a s obzirom na bitnost pridržavanja unaprijed propisanih procedura i okvira, podrazumijeva fizički odnosno kontaktni postupak glasovanja, odnosno fizičko ili kontaktno održavanje onog dijela sjednice u kojem se provodi takvo glasovanje. Drugim riječima, odlučivanje o onim točkama dnevnog reda sjednice kolektivnog tijela za koje je statutom propisano tajno glasovanje može se provesti samo pomoću glasačkih listića uz primjenu odnosno poštovanje epidemiološkog okvira propisanog Uputama o postupanju, koju je donio rektor Sveučilišta u Zagrebu dana 12. ožujka 2020. (Klasa: 115-01/20-01/2; Urbroj: 380-012/246-20-2) i Odluke o izvođenju nastave na daljinu, koju je donio rektor Sveučilišta u Zagrebu dana 13. ožujka 2020. (Klasa: 602-04/2011/03; Urbroj: 380-010/076-20-01) te preporuke za rad stručnih službi Sveučilišta u Zagrebu i svih njegovih sastavnica u vezi s pojavom koronavirusa i bolesti COVID-19, koji je donio rektor Sveučilišta u Zagrebu dana 16. ožujka 2020. (Klasa: 030-02/20-01/04; Urbroj: 380-012/246-20-1) te odredbe točke V. Odluke Stožera civilne zaštite RH o mjerama ograničavanja društvenih okupljanja, uslužnih djelatnosti i održavanja kulturnih i sportskih događaja (Narodne novine broj 32/2020) od 19. ožujka 2020. i točke II. Odluke Stožera civilne zaštite RH o izmjeni i dopuni Odluke o mjerama ograničavanja društvenih okupljanja, uslužnih djelatnosti i održavanja kulturnih i sportskih događaja (Narodne novine broj 48/2020) od 18. travnja 2020. te Preporuke Sveučilišta u Zagrebu za preddiplomsku, diplomsku i poslijediplomsku nastavu tijekom pandemije COVID-a 19 od 7. svibnja 2020. Iznimno, kolektivna tijela Sveučilišta u Zagrebu i njegovih sastavnica koja su održala tajno glasovanje elektroničkim putem na način da nitko pa ni administrator elektroničkog sustava Sveučilišta u Zagrebu ili njegove sastavnice (tzv. sistem inženjer) nije imao mogućnost neposrednog uvida u tijek i rezultate tajnog glasovanja kao načina odlučivanja kolektivnog tijela, prema stajalištu Odbora za statutarna pitanja, smatraju se tajnim glasovanjem kao načinom odlučivanja kolektivnog tijela koje je provedeno u skladu s općim aktima Sveučilišta u Zagrebu odnosno njegovih sastavnica. Odbor za statutarna pitanja smatra da provođenje tajnog glasovanja, ukoliko nisu ispunjeni navedeni uvjeti, ne bi bilo skladu s pozitivnim propisima koji jamče anonimnost tajnog glasovanja kao načina odlučivanja kolektivnog tijela. 
Okolnosti pandemije te posljedice elementarne prirodne nepogode kao što je potres, utjecale su na promjenu oblika sveučilišne nastave na Sveučilištu u Zagrebu tako da se umjesto klasične, kontaktne, fizičke nastave od 16. ožujka 2020. do završetka nastave početkom lipnja 2020. isključivo izvodila kao nastava na daljinu. Usprkos propisanim protuepidemijskim mjerama, među kojima je i zabrana zadržavanja osoba u većim skupinama u prostorima javnih sveučilišta, i Odluke o načinu izvođenja nastave u osnovnim i srednjim školama kao i na visokim učilištima, te obavljanju redovnog rada ustanova u području predškolskog odgoja i obrazovanja Vlade RH, otvara se pitanje usklađenosti izvedbenog plana studijskog programa, odnosno plana izvođenja nastave u okviru akreditiranog studijskog programa sa stvarnom realizacijom svih oblika sveučilišne nastave, koja se izvodila kao nastava na daljinu uz uporabu digitalnih odnosno elektroničkih pomagala. Prema odredbama članka 20. stavak 10. Zakona o osiguravanju kvalitete u znanosti i visokom obrazovanju, sveučilišni studijski programi osnivaju se i izvode odlukom senata sveučilišta na temelju prethodne procjene jedinice za unutarnji sustav osiguravanja i unapređivanja kvalitete, koja prilikom procjene uzima u obzir uvjete propisane općim aktom što ga propisuju odredbe 26. ovoga Zakona. Sveučilišni studijski programi mogu se financirati sredstvima državnog proračuna samo na temelju ugovora sklopljenog s Ministarstvom, a uz prethodno dobiveno pozitivno mišljenje Agencije. Nadalje, u podzakonskom općem aktu, kojim se uređuju uvjeti za izvođenje sveučilišnog studijskog programa između ostalog propisani su sljedeći uvjeti:

1. naziv studijskog programa, te akademski, odnosno stručni naziv, koji se stječe po završetku studijskog programa;

2. analizu usklađenosti studijskog programa sa strateškim ciljevima sveučilišta;

3. predviđene ishode učenja koji se stječu ispunjavanjem pojedinačnih studijskih obveza, modula studija i ukupnog studijskog programa;

4. nastavne metode i sadržaj studijskog programa koji osiguravaju stjecanje predviđenih ishoda učenja;

5. za svaku studijsku obvezu dodijeljen je odgovarajući broj ECTS-bodova, koji se mjere cjelokupnim radom što ga student mora uložiti kako bi stekao predviđene ishode učenja u sklopu te obveze.

\section{PRAVNI PROPISI KOJI SE ODNOSE NA POČETAK AKADEMSKE GODINE 2020./2021. U DOBA PANDEMIJE}

Uslijed ljetnog poboljšanja epidemiološke situacije, tijekom srpnja i kolovoza 2020., i manjeg broja oboljelih s izraženijim simptomima, sasvim je razumljivo da je Hrvatski zavod za javno zdravstvo u suradnji s Kriznim stožerom Sveučilišta u Zagrebu izradio Preporuke za održavanje nastave na visokim učilištima u 
razdoblju pandemije uz primjenu protuepidemijskih mjera. ${ }^{19}$ Hrvatski zavod za javno zdravstvo i Krizni stožer Sveučilišta u Zagrebu pri izradi preporuka kao polazište preuzeli su Preporuke i smjernice za izvođenje nastave na visokoškolskim ustanovama u zimskom semestru akademske godine 2020./2021. stajališta Nacionalnog vijeća za znanost visoko obrazovanje i tehnološki razvoj ${ }^{20}$ (središnjeg strateškog tijela Hrvatskog sabora za upravljanje sustavom znanstvene djelatnosti i visokog obrazovanja) koje je zauzelo stajalište da je „klasični“ način izvođenja nastave najbolji i optimalan za sve programe koji su akreditirani kao takvi studijski programi (osim, naravno, u onom dijelu u kojem je eventualno predviđena nastava na daljinu). Prema Nacionalnom vijeću za znanost, visoko obrazovanje i tehnološki razvoj, osim samoga izvođenja nastave, „klasični“ način osigurava pretpostavke i za cjelovito formiranje mladih ljudi, studenata, u stalnoj interakciji s nastavnicima i kolegama studentima, te u životu u visokoškolskoj ustanovi u kojoj se obrazuju. To uključuje mnogo više od samoga nastavnoga procesa i nezamjenjivo je u cjelokupnom procesu dozrijevanja mladoga čovjeka u svim oblicima njegove osobnosti. Nacionalno vijeće za znanost, visoko obrazovanje i tehnološki razvoj ističe da sagledavajući pak sveučilišni i sav visokoškolski život kao važan dio života gradova, odnosno društvenih zajednica u kojima se on odvija, očito je da sveukupni život tih društvenih zajednica biva značajno osiromašen izostankom visokoškolskih aktivnosti u klasičnom obliku. Ističe se da sveučilišna nastava koju smo u ljetnom semestru akademske godine 2019./2020. nazivali „online“ to nije. Ističe se da su visoka učilišta, napose sveučilišta, i visokoškolski nastavnici koristili e-alate koji su im bili na raspolaganju u trenutku prelaska na oblik nastave na daljinu, odnosno na rad od kuće. Korištenje računalnih i digitalnih tehnologija koje nije bilo moguće koristiti na samom visokom učilištu ne postaje samim time „online“ nastava. Kolegij i sami studijski program, koji se može nazvati „online“ nastavom, mora biti zamišljen, planiran i akreditiran kao studijski program koji se izvodi kao „online“ nastava. Za akreditaciju „online“ studijskih programa Nacionalno vijeće za znanost, visoko obrazovanje i tehnološki razvoj donijelo je dokument pod nazivom Kriteriji i postupci za vrednovanje „online“ studija.

Nacionalno vijeće za znanost, visoko obrazovanje i tehnološki razvoj ističe da je najveći izazov u razdoblju pandemije održavanje kvalitete studija prema kriterijima uspostavljenim i zadanim akreditacijom sveučilišnog studijskog programa, odnosno naknadnom reakreditacijom. Diplome koje izdaje visoko učilište, napose sveučilište, moraju studentima jamčiti onu razinu kvalitete izvedbe studijskog programa, pa tako i ishoda učenja i vještina koje je utvrdilo nadležno tijelo za osiguravanje kvalitete u visokom obrazovanju, Agencija za znanost i visoko obrazovanje. Nacionalno vijeće ističe da se nastava u zimskom semestru akademske godine 2020./2021. odvija prema tri modela: prvi klasični model visokoškolske nastave uz

19 https://www.hzjz.hr/wp-content/uploads/2020/09/PREPORUKE_visoka_ucilista_31_08_2020. pdf, pristupljeno 3. XI. 2020.

20 https://www.nvzvotr.hr/images/stories/dokumenti_novi/Preporuke\%20i\%20smjernice\%20za\% 20 izvo\%C4\%91 enje\%20nastave\%20na\%20visoko\% C5\%A1kolskim\%20ustanovama\%20...pdf, pristupljeno 14. XI. 2020. 
možebitnu primjenu nastave na daljinu, do $20 \%$ ukupnog fonda sati nastave, drugi tzv. mješoviti model nastave gdje se vježbe, seminari, posebice u znanstvenom području biomedicine, odvijaju kontaktno, slijedom čega se predavanja mogu odvijati kao nastava na daljinu u većem postotku od propisanih $20 \%$ (koliko je moguće izmijeniti bez reakreditacije studijskog programa) i treći model, po kojem se svi oblici visokoškolske nastave izvode kao nastava na daljinu, gdje će se morati osigurati računalna i informatička infrastruktura, kako bi se studentima omogućilo digitalno virtualno okruženje prvenstveno laboratorija i vježbaonica.

Temeljne odrednice Preporuka za održavanje nastave na visokim učilištima u razdoblju pandemije uz primjenu protuepidemijskih mjera su:

1. Preporuke za održavanje nastave na visokim učilištima u razdoblju pandemije (u daljnjem tekstu: Preporuke) odnose se na izvođenje nastave (predavanja, seminari) i konzultacija te na provedbu ispita na visokim učilištima (sveučilištima, veleučilištima i visokim školama) u razdoblju pandemije.

2. Pozivaju se visoka učilišta na razradu i objavu smjernica za izvođenje vježbi kao posebnoga oblika visokoškolske nastave s raznorodnim sadržajem i oblicima da bi ih se, osim načelno, moglo obuhvatiti jedinstvenim preporukama.

3. Nastavnici i studenti su zajednica odgovornih i savjesnih akademskih građana i članova društva koji u razdoblju pandemije paze na sebe i druge, čuvaju i brinu se za svoje i zdravlje svojih kolega, suputnika i ukućana.

4. Visoka učilišta nastojat će i dalje održavati kvalitetu studija u skladu s kriterijima propisanima za studijske programe u postupcima inicijalne akreditacije, odnosno reakreditacije. Svi akreditirani studijski programi izvodit će se prema sadržaju dopusnica.

5. Visokoškolska nastava u pravilu se izvodi na klasični, kontaktni način, kao nastava uživo, uz prisutnost nastavnika i studenta na visokom učilištu, odnosno u drugim ustanovama i okružjima (gdje se izvodi praktična nastava), kad je tako predviđeno silabom, izvedbenim nastavnim planom ili informacijskim paketom, a iznimno kao nastava na daljinu kad je to propisano studijskim programom, silabom pojedinoga predmeta, izvedbenim nastavnim planom ili informacijskim paketom kad epidemiološke okolnosti i mjere to zahtijevaju.

Kroz Preporuke pozvani su visokoškolski nastavnici da radi održavanja kvalitete visokoškolske nastave redovito drže konzultacije uživo, uz potrebne propisane protuepidemijske mjere, a iznimno, ako to nije moguće, da studentima budu dostupni i za konzultacije na daljinu. Visokim učilištima je preporučeno da studentima, koji nemaju potrebnu informatičku opremu, omoguće pristup istoj, odnosno da im posudbom i zaduženjem ustupe informatičku opremu na korištenje. Kao iznimka propisana je mogućnost da se, zbog epidemiološke situacije i propisanih protuepidemijskih mjera Nacionalnoga stožera civilne zaštite $\mathrm{RH}$ i/ili lokalnih stožera, ispiti mogu održavati na daljinu. U tom slučaju visoko učilište mora osigurati pravednu i sigurnu provedbu ispita na daljinu. Preporuka jest, ako se ispiti i druge studijske obveze na visokim učilištima zbog epidemioloških okolnosti 
i mjera moraju održavati na daljinu, kako će se u tom slučaju izbjegavati pisani ispiti i pisane provjere znanja, a prednost će se davati usmenim ispitima i/ili ocjeni pisanih referata, ogleda, eseja i seminarskih radova. Pri provedbi ovih preporuka visoka učilišta upućena su na pojačano korištenje alata za provjeru vjerodostojnosti studentskih radova što ih posjeduju visoka učilišta. Preporučeno je visokoškolskim nastavnicima da prilagode tijek izvođenja svih oblika visokoškolske nastave samo nakon što utvrde da studenti, s obzirom na materijalne i tehničke uvjete te računalne vještine, mogu provoditi pojedine aktivnosti na daljinu. Visokim učilištima je naloženo osiguravanje provedbe mjera raskuživanja (prozračivanje, dezinfekcija, nošenje maski i razmak) tako da studentima budu što dostupniji informatički opremljeni prostori za samostalno studiranje u odgovarajućim terminima, prilagođeni rasporedom sjedenja.

U skladu s Preporukama Hrvatskog zavoda za javno zdravstvo i Vlada RH donijela je dana 3. rujna 2020. Odluku o načinu izvođenja nastave u osnovnim i srednjim školama kao i na visokim učilištima te o obavljanju rada u ustanovama predškolskog odgoja i obrazovanja u uvjetima epidemije (Narodne novine broj 99/2020). ${ }^{21} \mathrm{U}$ posljednjoj Vladinoj Odluci vidljiv je značajan pomak u nomotehnici, kako kod izrade naslova ovog općeg akta, tako i kod same strukture, te sadržaja glavnog, središnjeg dijela pravnog propisa. Za sustav visokog obrazovanja značajna je točka V. Odluke koja glasi: „Visoka učilišta dužna su, u akademskoj godini 2020./2021., postupati sukladno preporukama za održavanje nastave na visokim učilištima (sveučilišta, veleučilišta i visoke škole) s obzirom na epidemiju, Hrvatskog zavoda za javno zdravstvo. Čelnici visokih učilišta, u skladu s autonomijom sveučilišta i akademskom samoupravom, slobodni su organizirati rad ustanova tako da se nastava nesmetano odvija.“

\section{ZAKLJUČAK}

Iz spomenutih odredbi razvidno je da se sveučilištima kao i drugim visokim učilištima nalaže primjena epidemioloških mjera i preporuka HZJZ-a. Analizom sadržaja normativnog dijela Odluke Vlade RH o načinu izvođenja nastave u osnovnim i srednjim školama kao i na visokim učilištima te obavljanju rada u ustanovama predškolskog odgoja i obrazovanja u uvjetima epidemije, jasan je i nedvosmislen pristup u provedbi svih epidemioloških preporuka i mjera što ih je donio Hrvatski zavod za javno zdravstvo u suradnji s Kriznim stožerom Sveučilišta u Zagrebu. Kako su preporuke Hrvatskog zavoda za javno zdravstvo temeljene na Preporukama i smjernicama za izvođenje nastave na visokoškolskim ustanovama, u zimskom semestru, akademske godine 2020./2021. koje je donijelo Nacionalno vijeće za znanost, visoko obrazovanje i tehnološki razvoj razvidno je da je i Vlada RH svakako ostavila mogućnost i ovlast visokim učilištima, napose sveučilištima (zbog autonomije sveučilišta), da sama visoka učilišta organiziraju izvođenje

${ }^{21}$ https://narodne-novine.nn.hr/clanci/sluzbeni/2020_09_99_1876.html, pristupljeno 10. XI. 2020. 
visokoškolske nastave u skladu s preporukama Hrvatskog zavoda za javno zdravstvo. Kroz nomotehničku i normativnu analizu sadržaja pravnih propisa donesenih u sustavu visokog obrazovanja, od proglašenja epidemije odnosno pandemije koju je proglasio ministar zdravstva do razdoblja odvijanja više od polovice nastave u zimskom semestru akademske godine 2020./2021., analizirali smo primjenu načela razmjernosti u ograničavanju pojedinih akademskih i sveučilišnih prava i nadležnosti. Ostaje za raspravu te stručnu i znanstvenu analizu je li ograničenje bilo razmjerno ugrozi i jesu li središnja tijela državne uprave ipak prekoračila onu tanku nevidljivu crtu duha ustava i duha zakona. U svakom slučaju Vlada RH kao nositelj izvršne vlasti u Republici Hrvatskoj dala je ovlast visokim učilištima neka odluče o obliku i načinu izvođenja visokoškolske nastave. Vjerujem kako su čelnici hrvatskih visokih učilišta pri donošenju odluka o načinu i obliku izvođenja visokoškolske nastave uzeli u razmatranje računalnu i digitalnu infrastrukturu koju posjeduju njihova visoka učilišta, akreditirane odnosno reakreditirane studijske programe te osposobljenost i opremljenost studenata za praćenje nastave na daljinu. Živimo ipak u izvanrednim okolnostima i svakako je prijeko potrebno da sva tijela hrvatske akademske zajednice, sveučilišta i drugih visokih učilišta donesu potrebne akte kojima bi dali legitimitet i legalitet obliku i načinu izvođenja nastave u izvanrednim, pandemijskim okolnostima. Hrvatsko visoko obrazovanje steklo je bogato iskustvo u organizaciji i izvedbi visokoškolske nastave za vrijeme Domovinskog rata od 1990. do 1995. odnosno do 1998. kad je završila mirna reintegracija hrvatskog Podunavlja. Pismohrane i arhive hrvatskih javnih sveučilišta posjeduju arhivsku građu koja svjedoči na koji se način organizirala i odvijala visokoškolska nastava u Republici Hrvatskoj u vrijeme osloboditeljskog domovinskog rata za hrvatsku neovisnost u kojem je hrvatska akademska zajednica, njezini profesori i studenti, dala nemjerljivi doprinos kako na prvoj crti bojišnice tako i kroz znanstveni i općedruštveni rad. Bogato iskustvo u organizaciji i izvedbi nastave (autor ovih redaka sjeća se od skraćivanja predavanja, seminara i vježbi do uvođenja dodatnih ispitnih rokova i povećanja broja uvjeta s kojima se mogla upisati viša godina studija, odnosno nova akademska godina) bile su mjere koje su donosila hrvatska javna sveučilišta (Zagreb, Split, Osijek i Rijeka). Iskustvo stečeno u Domovinskom ratu svakako je potrebno primijeniti i u organizaciji i izvedbi visokoškolske nastave i u razdoblju epidemije i pandemije bolesti COVID-19. 


\section{FORMULATION OF LEGAL PROVISIONS IN THE SYSTEM OF HIGHER EDUCATION DURING THE COVID 19 PANDEMIC}

The author analyzes the formulation and passing of legal provisions in the area of higher education as a public service in the Republic of Croatia during the COVID-19 pandemic. It particularly emphasizes that a public service such as higher education was not prepared for work in the extraordinary circumstances due to the life and health threatening pandemic. Based on examples from the University of Zagreb, the Croatian Department of Public Health, Civil Protection Headquarters and government of the of Republic of Croatia, acts were analyzed which were passed with the aim of implementing injunctions, orders, directives, measures and recommendations for uninterrupted carrying out of higher education activities. Particular attention was paid to the legal opinion regarding the process of selecting the heads of constituents of the University of Zagreb and the decision making process of the collective bodies of the University of Zagreb during the pandemic. It is essential that all bodies of the Croatian academic community, universities and other tertiary education institutions bring in the necessary acts whereby legitimacy and legality to the form and methodology of teaching in extraordinary, pandemic circumstances would be given.

Key words: legal provisions, higher education, COVID-a 19 pandemic, quality, recommendations 